\title{
THE POTENTIAL OF KALANGKALA (Litsea angulata) SEED EXTRACT AS A NATURAL SPERMICIDE MATERIAL
}

\author{
${ }^{1}$ Rommy Akmal, ${ }^{2}$ Rusmiati, ${ }^{2}$ Heri Budi Santoso \\ ${ }^{1}$ Alumny Department of Biology, Faculty of Mathematic and Natural Sciences \\ ${ }^{2}$ Department of Biology, Faculty of Mathematic and Natural Sciences \\ Lambung Mangkurat University, Banjarbaru, South Kalimantan, Indonesia \\ Email: rusmiati39@ymail.com
}

\begin{abstract}
Kalangkala (Litsea angulata) is one of the endemic plants in the wetlands area in Kalimantan which seeds are can reduce the quality of male mice spermatozoa such as motility and mobility. The purpose of this research is to know the potential of kalangkala seed extract on other parameters of spermatozoa quality, which are viability and morphology of male mice spermatozoa in an effort to obtain natural spermicide material. This research used five treatments by using twentyfive male mice. The design of this research was spermatozoa suspensions without being treated (Control $=0$ ), spermatozoa suspensions +Na-CMC $\quad 0,5 \% \quad(P 1), \quad$ spermatozoa suspensions + extract of kalangkala seed $0,1 \%$ (P2), spermatozoa suspensions + extract of kalangkala seed $0,3 \%(P 3)$, and spermatozoa suspensions + extract of kalangkala seed 0,5\% (P4), with five repititions for each treatment. The result of this research showed that the kalangkala seed extract reduce the percentage of viability of spermatozoa and increased the percentage of abnormal morphology of spermatozoa male mice. Therefore, kalangkala seed extract has potential as a natural spermicide.
\end{abstract}

Keywords : Kalangkala seed, Morphology, Spermatozoa, Viability

\section{INTRODUCTION}

The lower rate of men participation in family planning program is caused by limited contraception choices (only the use of condom and vasectomy). The use of condom is only $9 \%$ and $0.4 \%$ for vasectomy of total population in Indonesia (Nurliani \& Santoso, 2010). The materials for male contraception in Indonesia cannot be considered safe since they may cause irritation on penis and distraction of vagina epithelial cell (Sukrasno, 2003). Men participation in family planning is highly expected to make the program successful, then the options for male contraception must be varied (Husni and Sukesi, 2016).

Wetland in Kalimantan are very rich in a variety of exotic fruit both already have economic value and which still has potential economic value. One of the endemic plants found in Kalimantan which seeds have potential as antifertility agents is kalangkala (Litsea angulata) (Akmal et al., 2016). Based on the research by Mustikasari \& Ariyani (2010), this fruit-season plant is known for their sweet taste. The only part which is used is the flesh, not the seed. In fact, the seed contains alkaloid and tannin substances which can act as antifertility substance, particularly as spermicide (Asif, 2013). The research by Akmal et al. (2016) discovered that kalangkala seed extract, which is given in vitro, may reduce the quality of male mice spermatozoa such as motility and mobility to 0 .

The spermatozoa quality is still used as a significant parameter for men's fertility evaluation until today. That is why it is important to conduct a further research to know the potential of kalangkala seed on other parameters of spermatozoa quality which are viability and morphology of mice spermatozoa. Viability is needed by spermatozoa for surviving before reaching ovum (Fatmawati et al., 2016). The abnormal morphology of spermatozoa will slow down the mobility of spermatozoa for conception (Ermayanti \& Suarni, 2010).

Based on the above background, the problems of this research are: How the potential of kalangkala seed extract on viability and morphology of male mice spermatozoa?

The purpose of this research is to know the potential of kalangkala seed extract on the viability and morphology of spermatozoa male mice in an effort to obtain natural spermicide material.

\section{MATERIALS AND METHODS}

The research is conducted from October 2016 to January 2017 at Laboratory of Anatomy and Physiology, Faculty of Mathematics and Natural Science, University of 
Lambung Mangkurat, Banjarbaru, South Kalimantan.

\section{Simplicia processing of kalangkala seed}

The simplicial of dried kalangkala seed is made into powder and put into maceration vessel, stirred until methanol soak the powder 1 $\mathrm{cm}$ above the sample surface. The extraction is conducted for $5 \times 24$ hours, and every 24 hours the fluid is replaced and gathered. The filtrate from the maceration result, then evaporated using vacuum rotary evaporator on $40^{\circ} \mathrm{C}$ heating (Harbone, 1987). The evaporation is continued on waterbath on $40-45^{\circ} \mathrm{C}$ until strong extract is created.

\section{The $0.5 \% \mathrm{NaCMC}$ solution making}

0.5 gram of NaCMC is dissolved into 70 $\mathrm{mL}$ of hot aquades then cold aquades is added until $100 \mathrm{~mL}$. the $\mathrm{NaCMC}$ solution is used as placebo and solvent of methanol extract of kalangkala seed.

\section{Research design}

25 male mice of $\mathrm{Blb} / \mathrm{c}$, age 2-3 months, 20-30 grams in weight, are grouped based on Complete Random Design with 5 treatment group and 5 repetitions. The choice of treatment grouping pattern is based on Akmal et al. (2016) research, which are:

Control: Spermatozoa suspension is not added by anything

Placebo: Placebo, spermatozoa suspension which is added by $\mathrm{NaCMC} 0.5 \%$

Treatment I: Suspension is added by methanol extract of kalangkala seed $0.1 \%(0.01 \mathrm{~g}$ of strong extract $+10 \mathrm{~mL} \mathrm{NaCMC} \mathrm{0.5 \% )}$

Treatment II: Suspension is added by methanol extract of kalangkala seed $0.3 \%(0.03 \mathrm{~g}$ of strong extract $+10 \mathrm{~mL} \mathrm{NaCMC} 0.5 \%$ )

Treatment III: Suspension is added by methanol extract of kalangkala seed $0.5 \%(0.05 \mathrm{~g}$ of strong extract $+10 \mathrm{~mL} \mathrm{NaCMC} 0.5 \%$ )

\section{The extraction of epididymis cauda secretion}

Mice is dissected by neck dislocation. Its epididymis cauda is taken, and put into a witch glass of $1 \mathrm{~mL}$ of $\mathrm{NaCl}$ physiologic, then its cauda proximal is cut a little using scissors and pressed slowly to produce the secrete/epididymis liquid and suspended by $\mathrm{NaCl} 0.5 \%$, then stirred until homogenous.

\section{The observation of spermatozoa quality}

\section{a. Spermatozoa viability}

The analysis of spermatozoa viability is done by supravital painting, that is 1 drop of semen sample, suspended by $0.5 \% \mathrm{NaCL}$, is put on the object glass, then 1 drop of methanol extract of kalangkala seed is added, another 1 drop Eosin-Nigrosin solution is added, then stirred. It is deleted and dried in air. The observation is conducted on 100 spermatozoa under microscope using 400x enlargement. The living spermatozoa is colorless or transparent, while the dead spermatozoa is red, and the result will be presented in percentage (Suhadi and Arysad, 1983).

\section{b. Spermatozoa morphology}

The morphology examination is observed by Giemsa coloring. 1 drop of semen sample, suspended by $0.5 \% \mathrm{NaCL}$, is put on the object glass and added by 1 drop of methanol extract of kalangkala seed and 1 drop of Giemsa coloring. When it is dried, it is fixated using methanol for about 5 minutes until dry. It is colored using Giemsa coloring for 30 minutes, and washed by aquades and dried in room temperature. Morphological examination of spermatozoa is done by differentiating normal and abnormal spermatozoa from 100 spermatozoa observed, and the result will be presented in percentage. Observation are performed under a microscope using $400 \mathrm{x}$ enlargement (Suhadi and Arysad, 1983).

\section{Data Analysis}

The collected data are in quantitative (spermatozoa viability percentage, normal and abnormal spermatozoa morphology percentage) and in qualitative (mice spermatozoa morphology observation). The quantitative data in this research is analyzed using ANOVA ( $\alpha=0.05)$, and BNT/The Smallest Real Different Test and presented in mean and standard deviation. The qualitative data is presented in photos and analyzed descriptively.

\section{RESULT AND DISCUSSION}

The result of male mice spermatozoa viability analysis given kalangkala seed extract in vitro

The analysis result shows that giving kalangkala seed extract may lower the viability of mice spermatozoa Control (P0), Placebo (P1); Treatment $0.1 \%$; Treatment $0.3 \%(\mathrm{P} 2)$; Treatment $0.3 \%$ (P3); Treatment $0.5 \%$ (P4) for each: $75.60 \% ; 67.40 \% ; 15.00 \% ; 0.20 \%$. the spermatozoa viability can be seen in Figure 1 as follows: 


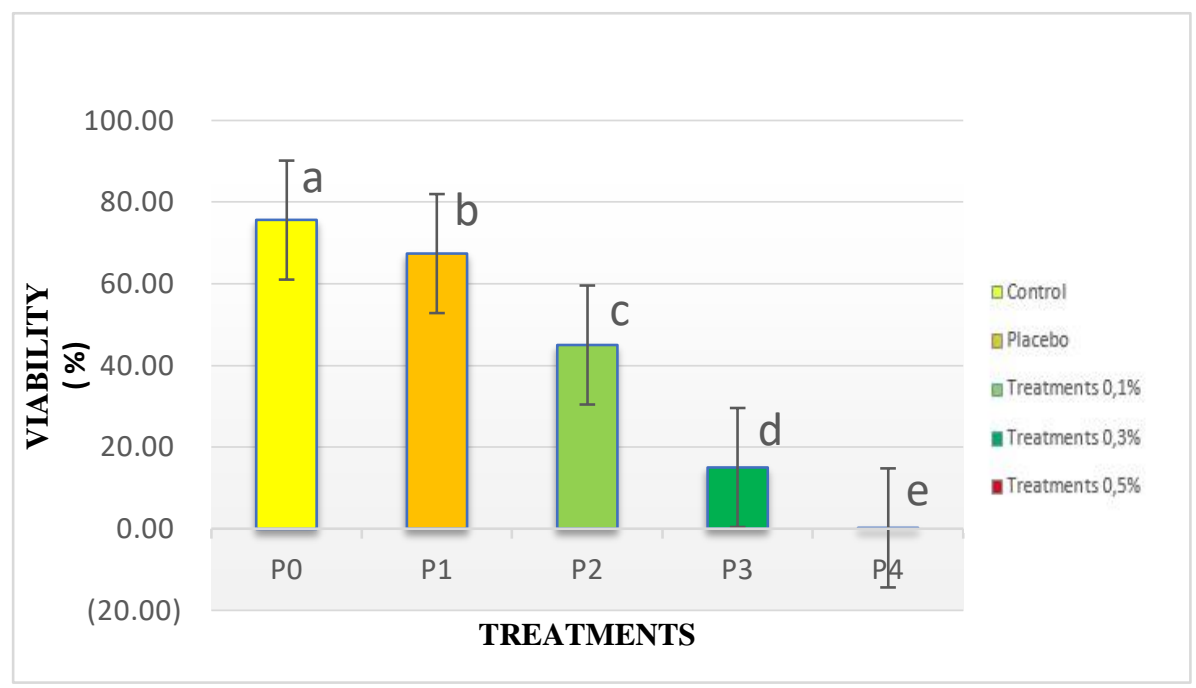

Figure 1. Histogram of spermatozoa viability mean after given kalangkala seed extract in vitro. Information: the same letter is not real different on BNT test $5 \%$

The description of living and dead spermatozoa viability after given kalangkala seed extract in vitro

The living and dead spermatozoa can be differentiated clearly using eosin-nigrosin coloring. The living spermatozoa is transparent and the dead spermatozoa is red.

The living and dead spermatozoa for each treatment can be seen in Figure 2, as follow:

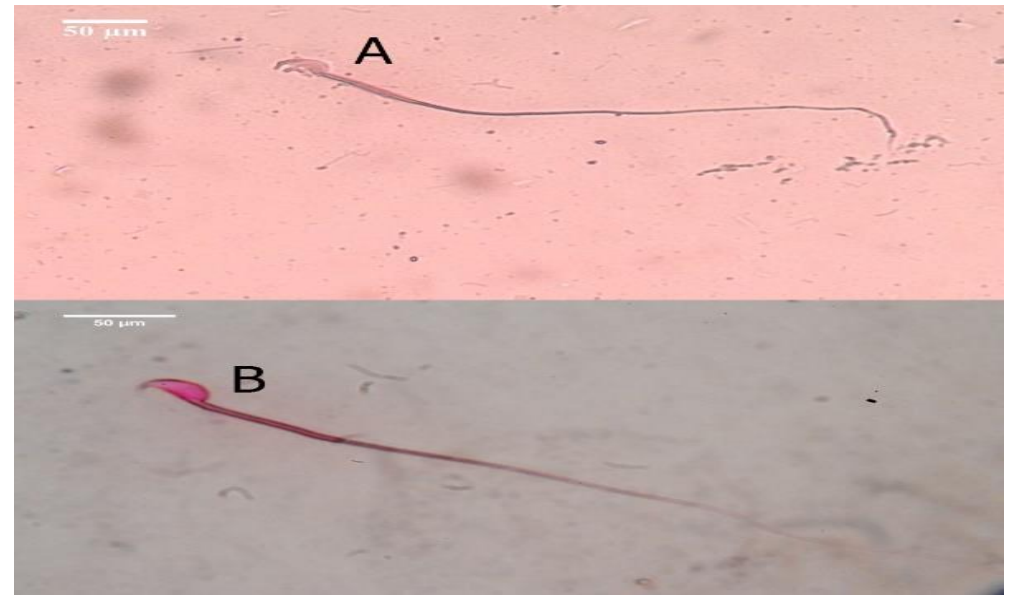

Figure 2. The description of mice spermatozoa viability after given kalangkala seed extract in vitro using Eosin-nigrosin coloring. 400x. enlargement (A) Living spermatozoa (B) Dead spermatozoa.

The morphology analysis result of male mice spermatozoa given kalangkala seed extract in vitro

The analysis shows that the given of kalangkala seed extract may damage the normal morphology of spermatozoa. Control
(P0); Placebo (P1); Treatment 0.1\%; Treatment $0.3 \%$ (P2); Treatment $0.3 \%$ (P3); Treatment $0.5 \%$ (P4) for each $22.40 \%$; $38.60 \%$; $63.00 \%$; $99.80 \%$. The spermatozoa morphology can be seen in Figure 3 as follows: 


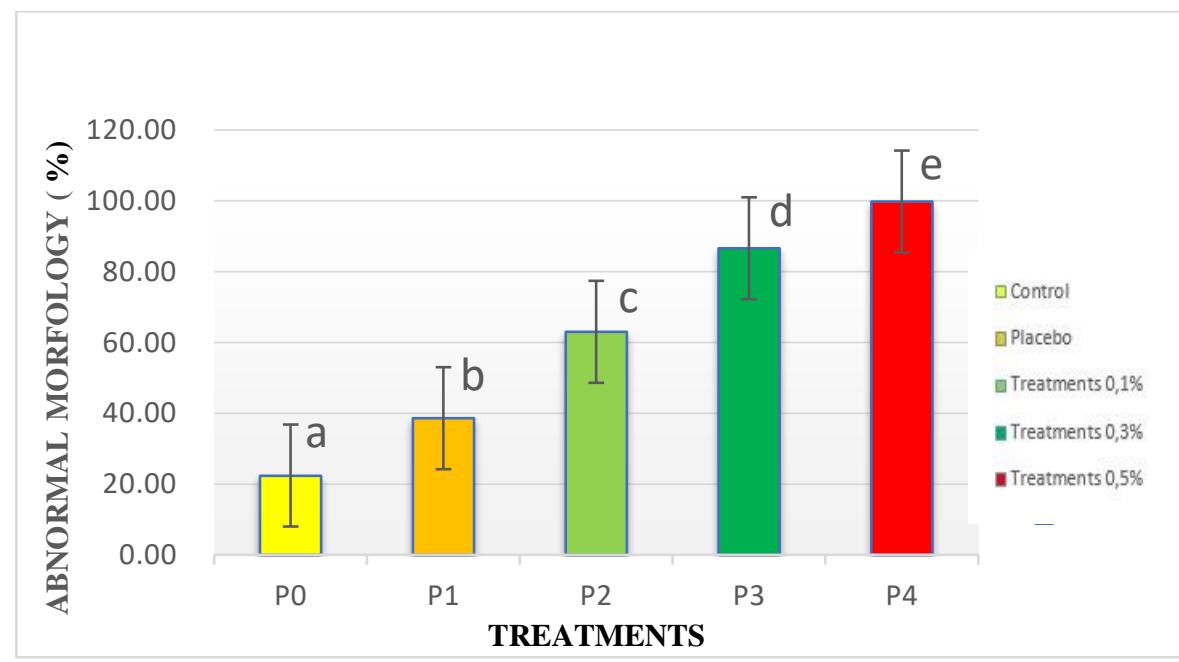

Figure 3. Histogram of abnormal spermatozoa after given kalangkala seed extract in vitro. Information: the same letter is not real different on BNT test $5 \%$

The morphology description of normal and abnormal spermatozoa

Spermatozoa with normal morphology has a head of curved acrosome, straight middle and single-straight tail. The normal and abnormal morphology of spermatozoa in this research can be seen on Figure 4 as follows:

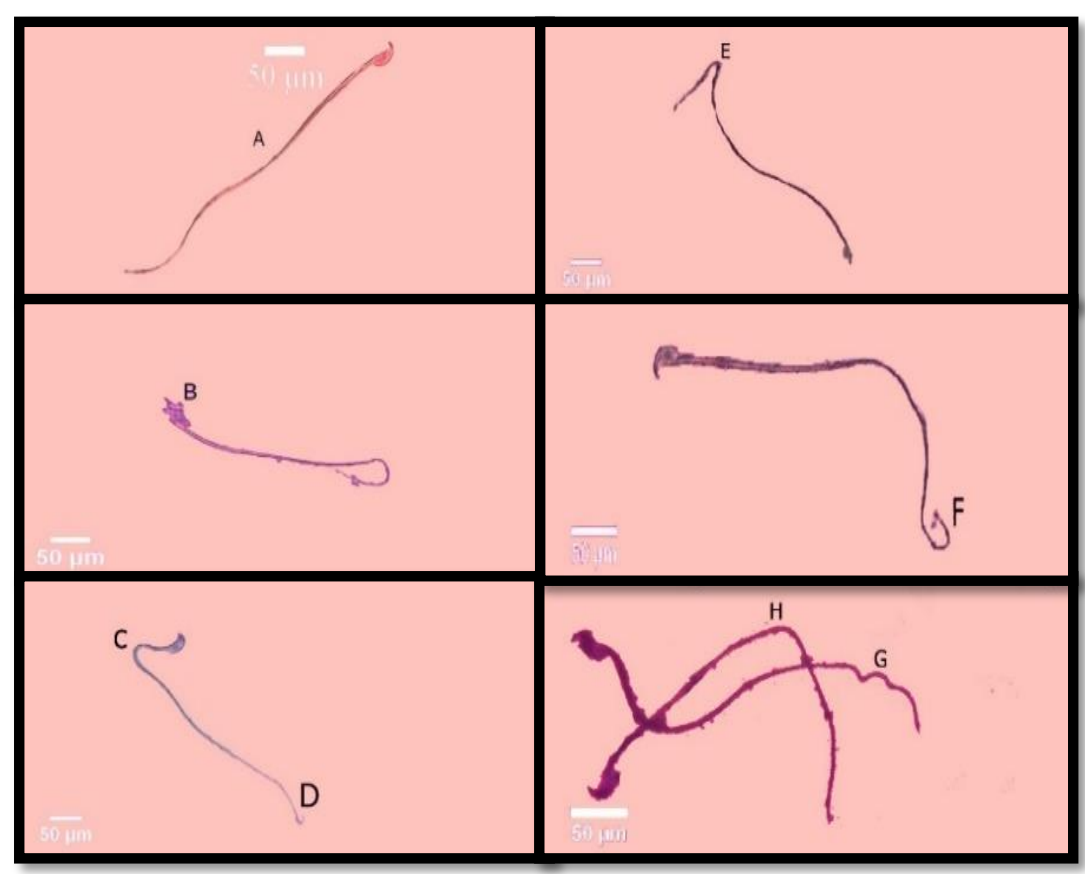

Figure 4. The morphology of mice spermatozoa after given kalangkala seed extract in vitro, using giemsa coloring. 400x enlargement. Normal Spermatozoa (A), lysis head (B), folded neck $(C)$, curled tail $(D, F)$, folded tail $(E)$, curled tail $(G)$, curved middle part $(H)$. 
Rommy Akmal, Rusmiati, Heri Budi Santoso: The Potential of Kalangkala (Litsea angulata) Seed....

\section{Viability}

The alkaloid and tannin content in the plant can lower the mice spermatozoa viability significantly (Fatmawati et al., 2016). Tannin can damage spermatozoa by damaging the plasma membrane integrity which cause the loosing of ATP and other metabolite substances in spermatozoa (Nurliani \& Santoso, 2010). Tannin can bind protein and ions inside spermatozoa membrane; this causes tyrosine enzyme and phosphorylation in spermatozoa membrane disturbed and leads to the death of mice spermatozoa (Sari et al., 2013).

Alkaloid can slow the energy from spermatozoa because it can produce free radical. The improved production of free radicals can disturb the osmotic balance and lead to the damage on spermatozoa tail area (Fatmawati et all, 2016). According to Ashfahani et al. (2010), the alkaloid substance in plant can disturb ATP-ase enzyme activity on spermatozoa membrane cell in tail area. ATP-ase enzyme has function to maintain internal homeostasis for sodium and potassium ions. If the $\mathrm{Na}+$ concentration is affected by homeostasis of broken sodium and potassium ions, $\mathrm{Ca} 2+$ produced will be reduced and losing the ability to carry solved substances into cytoplasma. This disturbed spermatozoa membrane permeability will cause transport of nutrient for spermatozoa to survive is also disturbed.

\section{Morphology}

The damage of mice spermatozoa which is given kalangkala seed extract is located partially on head and tail areas. This is caused by the distraction of alkaloid and tannin from kalangkala seed extract. According to Guyton \& Hall (2007), spermatozoa cells contain some enzymes. Those enzymes are significant for the spermatozoa to concept the ovum. The damage on head - lysis can damage the integrity of membrane cell which cause the content of the spermatozoa head expelled. While the damage on tail area is significantly affected its permeability, and cause the tail curled, bent or folded. According to Thakur et al. (2014) this condition of spermatozoa is known as hypoosmotic.

According to Adam et al. (2014) if the sperms in hypoosmotic condition, then automatically the sperms are trying to get the osmosis balance which can be seen from the curled, bent, or folded tail. According to Adam et al. (2014) the mobile ability of spermatozoa must be in normal morphology; the normal morphology of spermatozoa is having head, middle part and tail without abnormalities and damages so it can move front fast.

\section{CONCLUSION}

Kalangkala seed extract reduce the percentage of viability of spermatozoa and increased the percentage of abnormal morphology of spermatozoa male mice. Therefore kalangkala seed extract has potential as a natural spermicide.

\section{REFERENCES}

Adam, K., L. Fitria, \& M. Sarto (2014). The effect of giving seahorse protein fraction extract (Hippocampus kuda Bleeker, 1852) on the increase of mice hemoglobin level (Mus musculus L). Indonesia Pharmacy Journal 4: 83-90

Afiati, F., Yulnawati., Riyadi, M. \& Arifiantini, R.I. (2015). The abnormalities of lamb spermatozoa with different shelter frequency. Pros SemNas Masy Biodiv Indon 1: 930-949.

Akmal, R., Kuswanto, Fahrunnisa, S., Rahmi, R.A., Bayanil, N.E. \& Nurliani, A. (2016). The effect of kalangkala seed spermicide methanol extract (Litsea angulata) on mice spermatozoa (Mus musculus). Journal of Agromedicine and Medical Sciences 2: 18-23.

Asif, M. (2013). A Review on Spermicidal Activities of Azadirachta Indica. Journal of Pharmacognosy and Phytochemistry. 1: 61-79.

Badan Pusat Statistik (2010). Population Census 2010. Retrieved July $14^{\text {th }}$ 2016 from www.Sp2010.bps.go.id.

Ermayanti, N.G.A.M. \& Suarni, N.M.R. (2010). The quality of mice spermatozoa (Mus musculus L.) after Amargo wood infuse treatment (Quassia amara Linn.) and its recovery. Journal of Biology. 1: 45-49

Fatmawati, D., Isradji, I., Yusuf, I. \& Suparmi. (2016). The quality of male mice Balb/C after Kepel fruit extract treatment (Stelechocarpus burahol). MKB. 3: 155-159

Guyton, A.C. \& Hall, J.E. (2007). Book of Medical Physiology. $11^{\text {th }}$ edition, translated by Setiawan Irawati. EGC. Jakarta. 
Rommy Akmal, Rusmiati, Heri Budi Santoso: The Potential of Kalangkala (Litsea angulata) Seed....

Husni, Ervi \& Sukesi (2016). The effect of red seed guava active substance (Psidium Guajava L) on white male mice spermatogenesis (Rattus norvegicus). Ners Journal. 2: 269276.

Munandar, A., Nurcahyani, N. \& Busman, H. (2013). The Effect of Noise on Mice Spermatozoa Quality (Mus musculus L.). National Seminar on Science and Technology V. Lampung.

Mustikasari, K. \& Ariyani (2010). Phytochemical screening of kalangkala seed extract (Litsea angulata). Science and Applied Chemistry 4: 131-136.

Nurliani, A. \& Santoso, H.B. (2010). The Effect of Durian wood skin spermaticide extract (Durio zibethinus Murr) on motility and mobility of human spermatozoa in vitro. Science and Applied Chemistri 4: 71-78.

Sari, I.P., Rahayu, S., \& Rizal, D.M. (2013). The infuse of Pacing leaves costus speciosus (koen.) J.e. Smith as the barrier of amount and quality of male mice Balb/C spermatozoa. Traditional Medicine Journal 18: 5966.

Sarwar, A.G., Arif, M., Khillare, B., \& Thakur, S.C. (2014). In vitro study of the contraceptive spermicidal activity of ensete superbum on human sperm. International journal of pharmacy and pharmaceutical sciences 6: 205-207.

Suhadi, K. \& Arsyad, K.M. (1983). Sprem Analysis. Airlangga University Press. Surabaya.

Sujoko, H., Setiadi, M.A. \& Boediono, A. (2009). The selection of Garut Sheep using Percoll Density Gradient Centrifugation Method. Veteriner Unud 10: 125-134.

Sukrasno (2003). Getting to know better Mimba, Multifunction Herb plant. Agromedia Pustaka. Jakarta. 